\section{Intermediary activities and agendas of regional cleantech networks in Sweden}

\section{Brita Hermelin}

Linköping University, Sweden

\section{Hans Rämö}

Stockholm University, Sweden
Environment and Planning C: Government and Policy $0(0) 1-17$

(C) The Author(s) 2016 Reprints and permissions: sagepub.co.uk/journalsPermissions.nav DOI: $10.1177 / 0263774 X 16644256$ epc.sagepub.com

@AGE

\begin{abstract}
A vision of cleantech has been implemented on an international scale with financial assistance, new organizations and programmes. Given the wider contexts of political and commercial promotion, this article investigates management and governance of eight cleantech networks operating in different regions in Sweden. The aim of this article is to explore how an integrated approach based on network theories of economic sociology and a regional development perspective can contribute to the study of network intermediaries. What roles do intermediaries play in triplehelix networks? A suggested answer to this question is a typology of three intermediaries: a brokerage function for business agreements, a facilitation function whereby actors facilitate various processes and co-ordinate arrangements and a legitimizing function involving activities conducted in the political and wider societal realms. The legitimiser role of regional cleantech networks has important feedback effects on the wider discourses of environmental development, of which cleantech is a particular and influential vision.
\end{abstract}

\title{
Keywords
}

Cleantech, governance, intermediaries, networks, regions

\section{Introduction}

The cleantech sector is understood 'as spanning a wide range of environmental technologies and processes, including renewable energy, nanotechnologies, energy efficiency and storage, materials, and other technologies and industrial processes' (Caprotti, 2012: 370). The cleantech sector exists to provide technologies and services that allow for more sustainable development of society. According to Caprotti (2012), the concept of a cleantech sector was born in the early 2000s, and the construction of the sector can be seen as characterized by ecologically modernizing discourses (cf. Gibbs, 2006). The discourse of ecological modernization comprises assumptions about modernization,

\section{Corresponding author:}

Brita Hermelin, Linköping University, Linköping 58I 83, Sweden.

Email: brita.hermelin@liu.se 
win-win scenarios and optimistic visions for the future. These assumptions are centred on the idea of progress aligned with ideologies that have a long history in Western thought and theories of social change. Thus, the framework of cleantech has been easily introduced, widely legitimized and supported in politics in many national settings (McLaughlin, 2012), including Sweden. For companies and organizations, this has meant that 'environmental management is changing from a cost centre to a profit centre' (Störmer, 2008: 34).

Overall, the cleantech sector encompasses a wide range of products, services and processes that are united in their shared goal of improving green and sustainable industrial development. Although the concept of cleantech may be framed in the wider discourse of the green economy, it has been claimed that it represents specific ideas of economicenvironmental efficiency, green growth and 'market environmentalism' (cf. Caprotti, 2012). This contrasts with the ways in which the green economy has been presented from a UN perspective, and the aspects of social sustainability and poverty reduction are important hall-marks of this perspective (Caprotti and Bailey, 2014; Georgeson et al., 2014). A vision of cleantech has been implemented with financial assistance, new organizations, meetings, agreements and programmes. Organizations and institutions on different geographical scales have been engaged. On the international level, there are specialized networks such as the International Cleantech Network and the Global Cleantech Cluster Association (Davies, 2013); moreover, the EU and OECD are engaged in promoting this sector. Given such international advancements of cleantech, there are now national industrial agendas to support it.

In the context of this wider background of international and national policy, and the commercial promotion of cleantech, this study investigates how cleantech networks are envisioned, manifested, governed and operated on the regional level. These cleantech networks form partnerships and governance initiatives and activities for sustainable development. The term 'governance relations' refers to hierarchical connections that integrate actors at different government levels and to horizontal relationships between different spheres of authority and sectors (Bulkeley and Betsill, 2005). From a governance perspective, it is has become important that a cleantech network is a 'multisectoral, multilevel, and multiactor phenomenon' (cf. Bulkeley et al., 2013; Gustavsson, 2009: 62). The combination of resources acquired from multifaceted governance interactions facilitates the creation of regional institutions (Goodwin, 2013). The political agenda of cleantech affects the direction of these regional networking initiatives and their development in cooperative arrangements (Collins et al., 2007; Horbach, 2008; Knowles and Espinosa, 2009; Posch, 2010).

Regional cleantech networks are formed by multi-organizational interactions, including interdependency between public and private sector organizations. Regions offer proximity between triple-helix stakeholders (e.g. universities, R\&D centres, businesses and the public sector) that may promote favourable collaborations in terms of research and development capacities at different phases of product life cycles (cf. Etzkowitz, 2012; Gelter and Gelter, 2013; Leydesdorff and Etzkowitz, 1996; Miller et al., 2014). The triple-helix concept indicates a shift from a dominant dyadic industry-government relationship towards a triadic university-industry-government innovation relationship and a hybridization of private and public actors in knowledge-based business creation (Leydesdorff and Etzkowitz, 1996; Ranga and Etzkowitz, 2013). The cleantech networks studied here illustrate triple-helix constellations and 'the politics of clustering' (Davies, 2013: 1287). In the literature dealing with industrial clusters, there are studies of the activities of intermediaries that call for further research into the subject (cf. Provan et al., 2007; Ingstrup, 2010; Lefebvre, 2013). 
As noted by Human and Provan (2000) (see also Glückler, 2007; Lowndess and Skelcher, 1998), public-private interactions and triple-helix organizations are more complex than dyadic relations between co-operating organizations such as joint ventures, strategic alliances and partnerships. This increasing complexity places great demands on the intermediary and governance interactions in a network. It is found that network governance supports social and knowledge bridges between previously isolated producer communities (McDermott et al., 2009). Intermediary governance is important in ensuring support for actors and their access to different types of resources (McCauley and Stephens, 2012; Moss, 2009). Thus, the roles and complexities claimed for multi-organizational (Priestley and Samaddar, 2007) networks and governance processes make the study of regional cleantech networks' intermediary relations a relevant and pertinent theme, and is thus the focus of this article.

The aim of this article is to explore how an integrated approach involving network theories of economic sociology and a regional development perspective can contribute to the study of network intermediaries. The main research question is: What roles do intermediaries play in triple-helix networks? The empirical data of the article consider eight cleantech networks^ and include^ a focus on multi-organizational networks. These networks operate in eight regions in Sweden.

The article proceeds as follows. In Network intermediaries and regional settings section, the theoretical framework of the study is outlined in a discussion of network interactions, social networks and the regionalization of institutions. The empirical case of regional cleantech networks section presents the methodology and the empirical study, followed by two sections of analysis: Regionalization of cleantech initiatives section takes a regional institutional approach, while Intermediary activities on different geographical scales section explores the typology of the intermediary roles in cleantech networks. The conclusion in Conclusions: visions and activities of cleantech networks section stresses the multifaceted activities and roles of intermediaries in multi-organizational cleantech networks, and discusses how intermediary performance varies between regions and relates to activities on different geographical scales.

\section{Network intermediaries and regional settings}

This study draws upon the economic sociology and regional studies literature. Although these research fields are interrelated and have a common interest in network structures and processes, their respective disciplinary perspectives are different. Economic sociology tends to focus on the social effects and causes of various economic phenomena. Regional studies include the roles and activities of governance involving policy and public and private sector organizations, with a focus on their spatial dimensions. These research fields, and particularly their view of the role of network intermediation and governance, form the basis of this study. Governance in a regional sense has attracted interest as a consequence of the changing relationships between the public and private spheres of society.

Economic sociology focuses on the role of social capital in various network settings and refers to the stocks of social trust and norms that people in networks can draw upon to solve common problems. The value of social capital in networks can be described in terms of (i) closure, which affects access to information and facilitates sanctions and trust within a network (Burt, 2001; Coleman, 1988; Walker et al., 1997) and (ii) weaker connections and structural holes (i.e. absence of certain connections) between groups of people in a network (Burt, 2005; Walker et al., 1997). Although the macro-level consequences for intermediaries 
in networks have also been addressed by studies such as that of Stovel and Shaw (2012), these primarily consider their impact on the permeability of group boundaries.

The gap-bridging activities of intermediaries engaging in business activities are typically intended to bring a seller and buyer together, but they also aim to connect other actors or organizations for resource sharing without immediate financial concerns. Intermediaries between organizations are particularly necessary when there are information, knowledge or resource gaps in the existing organizations (Clarke and Ramírez, 2013; Howells, 2006; Kirkels and Duysters, 2010; Sapsed et al., 2007).

Network theories from economic sociology are important for exploring intermediaries in regional networks, which are the focus of this article. In studies adopting such approaches, the systemic role of an intermediary has been described as that of a 'network broker' (e.g. Snow et al., 1992) or a 'network orchestrator' (e.g. Batterink et al., 2010; Dhanaraj and Parkhe, 2006). For example, in a controlled laboratory study, Broom and Smith (1979) identify five intermediary roles: expert prescriber, technical services provider, communication process facilitator, problem-solving process facilitator and acceptant legitimiser. In a similar early study of theoretical conceptions of intermediary behaviour in social systems, Gould and Fernandez (1989) identify five theoretical roles that can arise in a network: co-ordinator (in the same subgroup), itinerant broker (between two subgroups), gatekeeper (who controls access), the representative (who mediates with outside subgroups) and the liaison (between several subgroups). More recently, Spiro et al. (2013), in a study of organizational collaboration after Hurricane Katrina in 2005, find three classes of intermediary activities: transfer of information, matchmaking and co-ordination. Other related studies include that of Chaston (1999), who surveyed how intermediaries identify a propensity for co-operation among small manufacturing firms, whereas Moss (2009) shows how intermediaries can influence the pursuit of collective goals in water and energy utility collaboration. Most of these studies have focused on a single or a few desired intermediary effects and processes between particular partners and less on the multiple services of one intermediary. It has also been found that ignorance and opportunism can impede network governance, particularly when interorganizational relationships are characterized by negotiations in circumstances where either roles or norms are ambiguous (Schrank and Whitford, 2011; Whitford, 2012). In summary, although studies of network intermediaries are plentiful, the complexity of intermediation in triple-helix settings remains under-researched and poorly understood.

When discourses such as that of cleantech networking travel, they are translated in different ways depending on the institutional settings of the places and regions in which they are located (cf. Czarniawska-Joerges and Sévon, 2005; Wetzstein and Le Heron, 2010). Thus, it is important to understand how the outcomes of the cleantech discourse vary between regions and how these outcomes affect the agendas, actors and intermediaries of cleantech networks. Conceptualizing institutions is helpful to understand the similarities and differences between the regional networks investigated here. Institutions include established and taken-for-granted systems and societal agreements, and they are important back-drops for social interactions (Hodgson, 2006; see also Brunsson and Olsen, 1998). Institutions may be shared between regions and places, but they may also be specific to a location. Institutions have roles in regional trajectories (Martin, 2009; Rafiqui, 2009) and they may possess features that cause inertia in social institutional settings. Lock-in can emerge from institutional regional milieus where there is 'too much bonding social capital, for example' (Pihkala et al., 2007: 840). On the one hand, institutions are obstacles to change; on the other hand, they are the means to conduct goal-oriented and strategic work. Institutions contribute to predictability, which is important in the ability to plan and act to achieve future outcomes. 
Institutions include organizational and discursive elements that can be thought of as the 'rules of the game', by which policies and practices are constructed (Boden, 1994). The vision of cleantech has become a discursive element, and thereby a component of the rules of the game. Organizations and individuals are 'actors' in the game (Rafiqui, 2009). The regionspecific institutional context that is important to the development of organizations such as cleantech networks includes the predominant rules of the game in that region, for instance, the traditions of co-operation, trust and other forms of social capital in network relations. The feasibility of regional strategies depends on matching of regional institutions, as well as their capacity and 'institutional thickness' (Rodríguez-Pose, 2013). For the purposes of this study, the regional cleantech networks are explored in the context of the particular regional settings of formal and informal institutions. This involves governance interactions with public and private actors. Regional cleantech networks are considered an illustration of a more general trend in the involvement of local and regional authorities in sustainable governance (Bulkeley et al., 2013). Similarly, Bulkeley (2005) finds that governance implies a continuum of systems of functions that can be performed by a variety of state and non-state actors in combination (cf. Patterson et al., 2003).

Through the pre-conceptualizations of network intermediaries and the regional institutional approach outlined above, this article aims to discuss these two concepts in an integrated manner. The way in which intermediary management and governance processes are intertwined will be explored. This endeavour is approached through an empirical study that sets out to identify what regional cleantech networks 'do', including activities performed through these organizations and the effects of initiatives. The study considers the development and implications of eight cleantech networks operating in eight regions in Sweden.

\section{The empirical case of regional cleantech networks}

To explore the intermediary activities of cleantech networks, empirical data were collected through interviews and secondary material. The selection of the networks was based on the membership list of the Association of Swedish Environmental Technology Industries (ASSET; www.miljoteknik.org) and was initially discussed with the chair of the board of the association. ASSET is the umbrella organization for the Swedish environmental technology sector, and a member of the European Environmental Technology Suppliers Associations (EUCETSA). ASSET members are primarily companies, but may also be municipalities and municipally owned utility companies (http://asset.nu/en). On a national level, ASSET is associated with SymbioCity, a Swedish government initiative to promote sustainable urban development. SymbioCity is operated by Swedish enterprises in partnership with Business Sweden (BS). BS is the Swedish Trade and Investment Council, and is jointly owned by the Swedish government and private enterprises. Hence, ASSET is a textbook example of how policy frameworks that are defined and operate on different geographical scales are interlinked, and how their influence trickles down to sustainable governance constellations on the local and regional scales through regional cleantech networks.

The chairperson of ASSET and several board members were interviewed because of their roles as co-ordinators of regional networks. The networks investigated are located in eight regions in Sweden that together cover the majority of the country. Co-ordinators from all eight of the Swedish ASSET networks were interviewed (either by phone or face to face) and meetings were held. The empirical data also include secondary data and information, mainly gathered from the regional networks' websites (Table 1). 
Table I. Regional cleantech networks, sorted by number of staff.

\begin{tabular}{|c|c|c|}
\hline Name of network and location of office & $\begin{array}{l}\text { Number } \\
\text { of staff }^{\mathrm{a}}\end{array}$ & Website \\
\hline $\begin{array}{l}\text { Green Gothenburg/Study Visits } \\
\text { Sustainability }\end{array}$ & 21 & http://www.businessregion.se and \\
\hline Gothenburg, South-Western Sweden & & http://www.greengothenburg.se/ \\
\hline $\begin{array}{l}\text { Sustainable Business Hub/Green Tech } \\
\text { visits - Environment Business } \\
\text { Development in Southern Sweden } \\
\text { Malmö, Southern Sweden }\end{array}$ & 13 & www.sbhub.se \\
\hline $\begin{array}{l}\text { Cleantech Östergötland } \\
\text { Linköping, South-Eastern Sweden }\end{array}$ & 6 & http://www.cleantechostergotland.se \\
\hline $\begin{array}{l}\text { Green Business Region } \\
\text { Borlänge, Mid Sweden }\end{array}$ & 5 & $\begin{array}{l}\text { http://www.teknikdalen.se/p/verksamhet/hallbar- } \\
\text { utveckling/hallbar-utveckling/green-business- } \\
\text { region/799 }\end{array}$ \\
\hline $\begin{array}{l}\text { The Stockholm Cleantech Association } \\
\text { Stockholm, Eastern Sweden }\end{array}$ & 3 & http://www.smtc.se/ \\
\hline $\begin{array}{l}\text { Technical Visits - Sustainable Umeå } \\
\text { Umeå, North Eastern Sweden }\end{array}$ & 2 & $\begin{array}{l}\text { http://www.umea.se/mer/tema/miljo/ } \\
\text { technicalvisits }\end{array}$ \\
\hline $\begin{array}{l}\text { Sustainable Sweden, South East } \\
\text { Kalmar, South Eastern Sweden }\end{array}$ & 2 & http://www.sustainablesweden.se \\
\hline $\begin{array}{l}\text { Sustainable Business Mälardalen } \\
\text { Västerås, Central Sweden }\end{array}$ & 1 & http://www.susbiz.se \\
\hline
\end{tabular}

${ }^{a}$ Source: Website information in February 2014. Number of staff (above) refers to employees named on the website for each organisation.

A series of interview questions was developed to explore the intermediary activities of the networks. These questions concerned each network's background, inception, membership, ownership and financial resources and activities, as well as a self-evaluation of the added value for the members, participants, owners and the region/society. The co-ordinators who were interviewed legitimize and represent the networks to outsiders, and the interview data reveal their visions for and views of the networks. The interview questions were used as a guide for the conversations, rather than as a strict question-and-answer tool. This approach enabled the interviewers to structure the conversations in a way that obtained the most relevant information about the respondent's role as an intermediary. The respondents were asked to talk about and describe their work as co-ordinators of regional cleantech networks and the activities of the broader network. They were also asked to describe their intermediary activities and their particular circumstances. The purpose of the empirical data collection was to identify and conceptualize the key roles and activities associated with intermediary functions in regional cleantech networks. Notes were taken throughout each interview. The quotes from the interviews were translated and slightly amended for clarification.

The analysis of the empirical data from the interviews and secondary sources was guided by the theoretical framework defined in the section above, which integrates research models in regional studies and in economic sociology. This entailed being particularly mindful of intermediary features of the networks and their regional and institutional contexts. 
The analysis was explorative and intended to allow the authors to note inconsistencies and identify further aspects and nuances that would enrich the suggested conceptual framework.

The cleantech networks investigated in this study that operate at the regional level are multi-organizational in that they connect and involve organizations from different sectors, including politics and local and regional public sector bodies, higher education institutions (HEI), companies and trade organizations. Consequently, the cleantech networks include triple-helix interactions with the public sector, universities and private companies, and their interactions involve governance. Table 1 lists the eight Swedish regional cleantech networks included in the study. The numbers of staff members are derived from the websites of each network. The regional networks investigated share the characteristics of pursuing and monitoring networking activities, partnerships and outreach actions. The co-operative and outreach nature of these networks suggests that their activities are much broader and resources much greater than these summary figures indicate. The activities in these networks are discussed in greater detail in the next two sections, locating them first in a regional institutional setting and then in a typology of network intermediation.

\section{Regionalization of cleantech initiatives}

This section describes the eight cleantech networks, their regional settings and the different arrangements of partners. Although all these networks are involved in triple-helix interactions and governance, the findings illustrate that the regionalization of political visions of cleantech involves considerable differences between networks in terms of resources, formal arrangements and the rules of the game. The balance of engagements of the different triple-helix partners (i.e. the public sector, HEI and private companies) differs, and the presentation of the networks investigated in this section is structured according to the importance of the three different partners. In this way, the discussion reveals the institutional settings and conditions of the cases.

The importance of considering cases that involve public sector partners is evident for three of the networks in this study. Two of these seem to have the greatest financial resources. The regions around Gothenburg (in south-western Sweden) and Scania (in the southernmost part of Sweden) are two of the most populous regions of Sweden, and these networks enjoy significant support and legitimacy from regional political bodies. Green Gothenburg is integrated into the organization known as the Gothenburg Business Region, while the Sustainable Business Hub in Scania has substantial financial support from Region Scania. A third case for which support from the public sector is salient is Sustainable Umeå (in north-eastern Sweden), which is owned by the municipality, unlike the regional bodies of Gothenburg and Scania. This network contrasts with the others in that it is geographically remote. The founding of Umeå University in the mid-1960s has been a major factor behind the continuous growth of the city, which has a population of around 119,000 . In contrast, the wider regional environment of this city in the north of Sweden has seen a marked decline in its economy and population. This trend and its geographical location intensify the need for Umeå to be included and invited into wider geographical interactions and collaborations. Sustainable Umeå's website features its programme for technical visits, which aims to attract visitors from outside the region in order to facilitate and legitimize regional development.

The second category of partners in the triple-helix model is that of HEI. The available data show that Cleantech Östergötland, linked with Linköping University (in south-eastern Sweden) and Sustainable Business Mälardalen, linked with Örebro University and Mälardalen University College (in central Sweden), are the two network organizations in 
which universities provide the most substantial support for the network intermediary in knowledge facilitation and legitimacy. This means that the universities make major contributions to basic funding through ownership, membership fees and financial support for particular projects. The Cleantech Östergötland website shows that Linköping University was the initiator of this network organization. The Green Business Region in Borlänge is an example of how individuals - through their presence on various boards at the triple-helix organization Teknikdalen ('Tech Valley') and at the regional university college - are channels for interactions between partners in cleantech networks. The intermediary's brokerage services are of particular importance in this context. Such individual initiatives are more important in smaller and less densely populated regions such as Dalarna (in central Sweden where the Green Business Region is located) than in more urbanized environments such as Stockholm, where the Stockholm Cleantech Association operates. The Stockholmbased Royal Institute of Technology provides funding and legitimacy for the Stockholm Cleantech Association, but the extent of co-operative activities is less than in the previous cases. The Green Business Region in Borlänge in central Sweden is a special case. This network is situated inside a formally established triple-helix organization with a regional university college dating back to 1987 (Teknikdalen). This context has contributed to a safe and stable institutional setting that, importantly, has trust capital, which explains how this network combines conditions of short-term project funding with planning of activities for longer periods.

The third category of partners in the triple-helix is the private sector and companies. Whether member companies pay a fee, and if so how much, varies between networks. Sustainable Sweden Southeast (in Kalmar) seems to charge comparatively high fees for company membership, and these fees are an important source of funding. The board is dominated by representatives of the networking companies, although it includes a representative of the municipality and one from the regional university college. This means that the intermediary function is focused more on facilitating contributory processes than on brokering services. In addition, Cleantech Östergötland has many companies that pay membership fees. Moreover, the respondents from Green Gothenburg emphasize the role of companies in funding and co-operation. The automobile industry (particularly Volvo) is a central actor in this region's institutional context. A long-term development project for biogas-powered vehicles is an important focus for Green Gothenburg.

Some tentative conclusions may be drawn from the information presented above. One relates to the effects of political devolution and uneven organizational reform of regional bodies in Sweden. Gothenburg and Scania are two regions where regional political organizations have been consolidated into more powerful bodies with strong cleantech networks. In contrast, although Stockholm is the major economic region of Sweden, it lacks strong political regional organizations. Its regional cleantech network has far fewer resources and is weaker than those in Gothenburg and Scania.

The implications of the regional institutions for the rules of the game are apparent when much of the funding for network organizations comes from various projects run for specific periods. Thus, these networks are prone to volatility and vulnerability. In such situations, the social capital of trust is an important compensating variable. Although the respondents from the Borlänge and Västerås networks reported dependency on time-limited funding, both were confident about the prospects for continuity of their networks. In both these cases, the regional university colleges are important partners. This sense of confidence can be understood to affect the respondents' involvement with the regional network; their involvement in turn influences the rules of the game in that region. 
Successful governance means that the rules of the game in regional cleantech networking are recognized among the actors and partners involved. Both formal and informal rules regulate the behaviour and authority of individuals and groups. The complexity of governance arises from the large number of interacting network members, which are handled by an intermediary. In this way, intermediary management and governance processes are tightly intertwined, which motivates the detailed discussion on intermediary roles that follows in the next section.

\section{Intermediary activities on different geographical scales}

The studies of network intermediation mentioned in Network intermediaries and regional settings section have demonstrated that intermediary roles can take many forms. From the empirical material for this study, it is possible to distil certain tasks and activities at different levels of intermediary involvement - from one-to-one intermediation to outreach to the public, private stakeholders and interest groups. Although the boundaries are not strict, in the following section, we distinguish between three main categories that are related to bringing actors together, guiding processes and maintaining policy relationships.

At a general level, the interviews show that regional cleantech networks must manage organizational, economic and political issues. From the empirical cases, it is found that the regional networks have three main agendas. First, they organize technical visits that are primarily oriented towards external actors, that is, those from outside the region, whether national or international. Second, they invite regional actors to meet, and third, they support regional actors in obtaining funding from national or international programmes. Thereby, there is an agenda of outreach to industry and policy audiences, a knowledge agenda directed towards helping members to share expertise and a funding agenda to support the development of both members and the regional network itself. These activities and agendas share the feature of being hands-on. Cleantech networks are established in the discursive contexts of green development and sustainable governance and have goals involving economic growth. They are experienced as being clearly targeted at business:

'Our financiers want results from our business members in the form of increased sales, profits, value added, and number of employees' (Respondent from network 3).

The empirical examples of the eight networks illustrate the complexities of regional triplehelix networks in terms of intermediary governance and show that they perform different activities: bringing together people in the same business and those from other domains and sectors, seeking funding support and negotiating and obtaining political legitimacy. Intermediary roles may be categorized into the following tripartite typology. First, there is a brokerage role of acting more or less on a one-to-one basis by helping actors to secure early co-operation and specific interactions with partners. Second, there is a facilitator role, in which intermediators of the networks guide people through various political agendas, processes and co-ordinated arrangements. Third, the networks perform a role that could be called that of a legitimiser, which means to invite selected people to join the network and to act as a legitimacy-building intermediary between the network members and the political and public realm. The first two intermediary functions of broker and facilitator are relatively well known, and are central elements of the economic sociology approach to networks that was reviewed in Network intermediaries and regional settings section. These roles entail specific and direct actions. The function of brokering resembles roles such as those of coordinator and itinerant broker (Gould and Fernandez, 1989), along with matchmaking and co-ordination (Spiro et al., 2013). The facilitator role shares features with that of a 
communication process facilitator (Broom and Smith, 1979). Although a review of the literature finds less emphasis on the third role, that of the legitimising actor, this is nevertheless an aspect of roles such as that of acceptant legitimiser (Broom and Smith, 1979) or representative (Gould and Fernandez, 1989) and the actions of intermediaries to realize collective goals (Moss, 2009).

Existing studies show the various intermediary roles, but without bringing them together in a regional context, an aim that is pursued in this article. The integrated approach of this article is supported by interviews wherein respondents describe aspects of intermediary governance with multiple roles and objectives. This is in contrast to the existing articles' main focus on single intermediary cases. In this way, the integrated approach of network theories of economic sociology and regional development perspective have supported the analysis and highlighted the multiple roles of intermediaries in regional networks. In particular, the importance of the complex role of legitimising is perceived to exist along with the more obvious roles of broker and facilitator.

An intermediary is someone who acts as a go-between or a mediator between two or more actors (Latin inter-, 'between' and medius, 'the middle'). Both brokers and facilitators are 'go-betweens' or intermediaries between actors. The broker (Anglo-French brocour, 'small trader') acts as a direct bridge between actors, and the facilitator (Latin facilis, 'to make easy') acts to enhance the effectiveness of the group or network. The third category of network processes, the legitimiser (Latin legitimare, 'make lawful'), plays a role both in choosing and accepting members into the network and in legitimating the network in political and wider societal discourses.

To understand the intermediary roles in regional cleantech networks, different agendas for relations on different spatial scales must be considered. Therefore, this analysis of activities has a geographical perspective and distinguishes between the regional, national and international relations of cleantech networks.

At the regional level, the brokerage function clearly focuses on giving local cleantech actors an opportunity to meet and exchange experiences. Several respondents (e.g. in Stockholm and Västerås) stressed that local actors mainly wish to meet other actors and businesses in the same field. This is because the cleantech area is extremely broad. This study also found examples of network activities, leading to the matching of regional clients and suppliers in a variety of industries with the aim of reaching business agreements (e.g. in Linköping and Borlänge). In this context, the particular focus is the formation of bridges between industries and support for small companies. Such brokerage activities are illustrated by the following quotes:

\footnotetext{
'We organized a seminar about [thermal] windows and invited customers and suppliers. This led to a business agreement between a small company to develop and supply windows to a major regional construction company.' (Respondent from network 4)

'I talked to the political chairpersons of four municipalities in the region about the possibility of developing a shared biogas plant. We pitched this idea to a suitable consultant who could investigate such a project.' (Respondent from network 4)
}

It became clear from the interviews that regional business actors rarely limit themselves to discussions with colleagues in their region alone. Instead, they seek more distant partners. At the national level, the brokerage function specifically focuses on bringing together cleantech actors from different parts of the country. The brokerage function at the international level involves small and medium-sized businesses in the regions that receive support to promote their exports. The cleantech networks arrange technical visits to the region by international 
companies, which provides important opportunities to make contacts that could lead to export opportunities:

'We put most of our energy into supporting our members in the development of their export activities.... We broker between suppliers and customers.^ (Respondent from network 2)

Cleantech companies are often small and unable to work in more than one [foreign] market; particularly not before they receive substantial income from sales. Therefore, we work strategically to attract clients to visit us in Sweden. In that way, we can support our companies in developing export activities. (Respondent from network 1)'

In summary, the brokerage activities bring together actors from both similar and different industries, and from the local region, other parts of Sweden and abroad. Once established, these contacts may then continue and develop into business co-operation. A clear focus on business value emerges from the interviews.

The second role in the proposed typology is that of facilitator, which provides a platform for communication and collaboration. Membership of the network gives access to a forum where companies can exchange ideas and obtain updated information from industry associations and government agencies. The regional platforms organize regular meetings that are sometimes open to the public, as well as internal and industry-specific meetings. Some of the networks arrange 15-20 open meetings and 20-30 internal meetings annually. Internal subject-specific meetings were regarded as particularly important, whereas the open and more general meetings were sometimes perceived as too general and primarily directed towards the public and journalists. Examples of subjects discussed at such meetings are as follows:

...educational activities, activities about financial sources, information about political systems and the demand for new solutions... (Respondent from network 1)

There are also comments dismissing the alleged focus on obtaining new business from cleantech networks:

It is popular among the companies to talk about techniques. The use of network interactions solely to obtain new business has been exaggerated. Other themes are also requested. (Respondent from network 5)

One of the respondents prioritized the role of being a facilitator, rather than a broker:

I am not very positive towards the expression 'matchmaking'... We facilitate contacts between our members and manufacturing companies. Then it is the responsibility of our members to take the next step to reach business agreements. We make the regional company network denser. Our seminar activities also involve the local authorities. (Respondent from network 7)

The facilitator role of networks on the national scale supports information exchange about changing directions as well as guidelines from the state and the government. This facilitator function primarily concerns dissemination of information from the top down.

We offer our companies guidance about financial support from national state bodies. (Respondent from network 4)

The facilitator at the international level can be seen as a platform provider that opens doors for international opportunities and information exchange. Several networks include international co-operation; for example, water purification projects in southern Africa (e.g. in Botswana) and various activities in China. These activities provide an opportunity 
for the regional network members to visit projects in other countries and to receive visitors from outside. Programmes for technical visits involve incoming international visitors.

In summary, the role of a facilitator can be seen as providing information pertaining to regional, national and international frameworks and activities. Facilitator services are important for access to information about funding programmes from national or international bodies and organizations.

The third intermediary function of the proposed typology is that of the legitimiser. At a regional level, the role of the legitimiser is to participate in the creation of regional political recognition. This role has two functions. First, the network identifies those that can be said to work in the cleantech field in the region. Second, the network liaises with regional political actors. These functions serve to legitimise the network's activities in the eyes of the public and the political authorities that provide the main funding for many of the regional networks. The legitimiser vouches that the network is a reputable actor in the regional political landscape and is entitled to financial and political support. At the national level, the legitimiser participates in the national business policy agenda. ASSET, the national network of Swedish regional cleantech organizations, has a role at the national level. Stakeholders in the regional organizations are supported by ASSET's legitimacy in the field and at the national level. One example of such legitimacy work is the involvement of the regional networks in defining and mapping the Swedish cleantech sector (Vinnova, 2013). This institutionalizes and promotes the idea that 'cleantech is about value chains and systems' (Respondent from network 1). The regional cleantech networks are also present in international contexts, for example, when Swedish showcases are presented at EU meetings abroad, as well as during visits of foreign politicians to regions in Sweden. International outreach activities and incoming international technical visits to the regional networks are channels for influencing the direction of international cleantech policy and envisioning. These efforts require legitimisation.

The network websites are an important element in the legitimising function, as was the respondents' willingness to participate in this study. Through the interviews, the coordinators provided examples of successful activities that may be disseminated to wider audiences through presentations and publications. Thus, the co-ordinators of the networks are key actors in the legitimiser role for the political facets of cleantech networks at the regional, national and international levels.

As outlined above, the multifaceted activities, roles and functions of the regional cleantech networks that were investigated may be reflections of their multi-organizational nature. Regional cleantech networks include organizations that have different and possibly conflicting agendas. Entrepreneurs employ the networks for commercial purposes. University staff usually seek collaborative network opportunities and funding for research work. Regional policy may target growth effects. Not only are there differences and possible conflicts concerning the visions of partners but also regarding the locations of the activities. Thus, intermediary governance in such environments is not only complex but can also be somewhat disappointing when expectations in general cannot be met because of competing agendas amongst the network members (cf. Davies, 2004).

Considering the various roles identified in the typology of network intermediaries, legitimising activities may be a joint interest shared by all parties. Securing and enhancing the external legitimacy of the network in political and official discourse depend on decisions about whom to accept into the network, on the ability of the intermediary to create and maintain good relations with public and private partners outside the network, and on the ability to be recognized and visible in wider contexts. The influential discourse of the green economy and directions towards 'market environmentalism' discussed in the introduction 
guide parties from different sectors to agree on the importance of the business and economic aspects of green development. These also involve facets of the rhetoric and the legitimisation of the cleantech networks studied.

\section{Conclusions: Visions and activities of cleantech networks}

Through the empirical study of eight cleantech networks operating in different regions in Sweden, network theories of economic sociology have been explored from a geographical perspective. The networks investigated were presented according to their regional institutional contexts, and we explored how these contexts represent variations in triplehelix constellations. The regional contexts and harnessing of regional resources for the cleantech networks varied between the networks, which are related to aspects of financial support as well as to institutional settings and trust capital.

This article set out to explore how an integrated approach to network theories of economic sociology and a regional development perspective can contribute to the study of network intermediaries, particularly in situations where multiple agencies co-operate.

A theoretical framework was derived from the integration of research models in regional studies and in economic sociology, and the visions and activities of the networks were examined through the exploration of their intermediary activities. The intermediary activities of the cleantech networks not only take advantage of business opportunities but also gain political legitimacy, and the typology of brokering, facilitating and legitimising has been suggested as a way of understanding intermediary activities in regional cleantech networks.

First, the role of the broker is to connect different actors for business purposes. Cleantech networks are established in the discursive contexts of green development, with goals around economic growth, and are found to be distinctly targeted at business.

Second, the facilitator role concerns the governance of information-focused activities, with involvement in and knowledge about financial issues relating to regional, national and international project funding.

Third, the legitimiser role concerns governance and politics. At a regional level, intermediaries strive to develop attractive regional and place brands; at a national level, they seek to be involved in the national political programmes and visions of sustainable development; and internationally, they advocate sustainable development.

The broker and facilitator roles were derived directly from the interview data and the network managers' descriptions of the missions and activities undertaken. All but one of the informants described one or both the activities of brokering and facilitating. The exception (Umeå) is characterized by rather limited resources, and the activities of this network primarily focus on organizing technical visits.

Overall, the view of cleantech discourse as driven by business seems to be generally applicable regardless of the regional set-up of the networks and descriptions of their intermediary activities. This is an aspect with implications for the profile of the legitimising activities conducted by the networks. The legitimising activities were not directly spelled out by the informants in the interviews; hence, this aspect was identified through conceptualization of the discourse context of cleantech. The networks are embedded in a commercially driven view of the green economy.

Legitimisation means alignment with the rules of the game, and thus integration into supportive institutional contexts. The role of legitimiser in the networks can be indirectly observed in the way in which these organizations choose to present their activities in interviews and on websites, and from the way in which they obtain and allocate resources and are integrated into regional governance activities. 
The proposed typology of intermediary functions indicates the complexities of management and governance interactions in regional cleantech networks. Such multiorganizational networks are exposed to different expectations and perspectives. Members from different sectoral backgrounds and agendas bring expectations to the network that may be divergent and not always easily met by the intermediary. Thus, while regional networks share discourses, key visions and agendas, there are also differences in the composition, resource mobilization and actions of each particular regional network. This finding identifies implications of regional institutional settings, which produce spatially uneven governance processes. This implies that the prospects and future pathways of cleantech activities vary between regions. Because of the trans-regional and international interactions of the networks investigated, these different forms of regional initiative also exert influence on the wider green economic development.

To conclude, we revisit the research question of this article, which was: What roles do intermediaries play in triple-helix networks? The answer to this question is a suggested typology of intermediaries, which includes the roles of broker, facilitator and legitimiser. It is hoped that the empirical findings presented through the article have illustrated that intermediary management and governance processes are tightly intertwined and that the suggested typology of intermediary roles of cleantech networks have illustrated the advantage of cross-disciplinary integration of economic sociology and regional study perspectives. The integrated approach to network theories and the regional development perspective are important for identifying the multiple roles of cleantech networks, which include the core aspect of the legitimiser role. This integrated approach may also be more widely applicable to the concepts of governance and regional networks and be valuable in revealing more explicitly how regional networks 'work' and what they 'do'. This is in line with arguments made by Malecki (2012) about the role of regional social capital in regional clusters as a 'process' in contrast to a 'thing' in attempts to understand how networks may be key 'trigger factors' for actions rather than entities and measurable resources in themselves.

The wider societal context of this article pertaining to the discourse and policies of cleantech means that the role of the legitimiser becomes significant. The focus on business values among the networks studied demonstrates how the legitimiser role of these activities reinforces the ideas of 'market environmentalism' that we found to signify the shared policy discourses of cleantech.

\section{Acknowledgements}

An earlier version of this paper was presented at RESER conference in Aix en Provence, France, in September 2013.

\section{Declaration of conflicting interests}

The author(s) declared no potential conflicts of interest with respect to the research, authorship, and/or publication of this article.

\section{Funding}

The author(s) received no financial support for the research, authorship, and/or publication of this article. 


\section{References}

Batterink MH, Wubben EFM, Klerkx L, et al. (2010) Orchestrating innovation networks: the case of innovation brokers in the agri-food sector. Entrepreneurship \& Regional Development: An International Journal 22: 47-76.

Boden D (1994) The Business of Talk: Organizations in Action. Cambridge: Polity Press.

Broom GM and Smith GD (1979) Testing the practitioner's impact on clients. Public Relations Review 5: 47-59.

Brunsson N and Olsen JP (1998) Organizing Organizations. Copenhagen: Copenhagen Business School Press.

Bulkeley H (2005) Reconfiguring environmental governance: ^Towards a politics of scales and networks. Political Geography 24: 875-902.

Bulkeley H and Betsill M (2005) Rethinking sustainable cities: Multilevel governance and the 'Urban' Politics of Climate Change. Environmental Politics 14: 42-63.

Bulkeley H, Jordan A, Perkins R, et al. (2013) Governing sustainability: Rio +20 and the road beyond. Environment and Planning C: Government and Policy 31: 958-970.

Burt RS (2001) Structural holes versus network closure as social capital. In: Lin K, Cook K and Burt RS (eds) Social Capital: Theory and Research. Sociology and Economics: Controversy and Integration Series. New York: Aldine de Gruyter, pp. 31-55.

Burt RS (2005) Brokerage \& Closure. New York: Oxford University Press.

Caprotti F (2012) The cultural economy of cleantech: Environmental discourse and the emergence of a new technology sector. Transactions of the Institute of British Geographers 37: 370-385.

Caprotti F and Bailey I (2014) Making sense of the green economy. Geografiska Annaler: Series B, Human Geography 96: 195-200.

Chaston I (1999) Existing propensity to cooperate: An antecedent influencing the potential performance of small-business networks? Environment and Planning C: Government and Policy 17: 567-576.

Clarke I and Ramirez M (2013) Intermediaries and capability building in 'emerging' clusters. Environment and Planning C: Government and Policy 31: 714-730.

Coleman JS (1988) Social capital in the creation of human capital. American Journal of Sociology 94: S95-S120. (Supplement: Organizations and institutions: Sociological and Economic Approaches to the Analysis of Social Structure. ${ }^{\wedge}$.

Collins E, Lawrence S, Pavlovich K, et al. (2007) Business networks and the uptake of sustainability practices: The case of New Zealand. Journal of Cleaner Production 15: 729-740.

Czarniawska-Joerges B and Sevón G (2005) Global Ideas: How Ideas, Objects and Practices Travel in a Global Economy. Copenhagen: Copenhagen Business School Press.

Davies A (2013) Cleantech clusters: Transformational assemblages for just, green economy or just business as usual? Global Environmental Change 23: 1285-1295.

Davies JS (2004) Conjuncture or disjuncture? An institutionalist analysis of local regeneration partnerships in the UK. International Journal of Urban and Regional Research 28: 570-585.

Dhanaraj C and Parkhe A (2006) Orchestrating innovation networks. Academy of Management Review 31: 659-669.

Etzkowitz H (2012) Triple helix clusters: Boundary permeability at university-industry-government interfaces as a regional innovation strategy. Environment and Planning C: Government and Policy 30: 766-779.

Georgeson L, Capriotti F and Bailey I (2014) It's all a question of business': Investment identities, networks and decision making in the cleantech economy. Geografiska Annaler: Series B, Human Geography 96: 217-229.

Gelter H and Gelter J (2013) An innovation lost. The Value of Arts and Culture for Regional Development: A Scandinavian Perspective Eds L Lindeborg, L Lindkvist. (Routledge, London).

Gibbs D (2006) Prospects for an environmental economic geography: Linking ecological modernization and regulationist approaches. Economic Geography 82: 193-215.

Glückler J (2007) Economic geography and the evolution of networks. Journal of Economic Geography 7: 619-634. 
Goodwin M (2013) Regions, territories and relationality: Exploring the regional dimensions of political practice. Regional Studies 47: 1181-1190.

Gould R and Fernandez R (1989) Structures of mediation: A formal approach to brokerage in transaction networks. Sociological Methodology 19: 89-126.

Gustavsson E, Elander I and Lundmark M (2009) Multilevel governance, networking cities, and the geography of climate-change mitigation: Two Swedish examples. Environment and Planning $C$ : Government and Policy 27: 59-74.

Hodgson G (2006) What are institutions? Journal of Economic Issues 40: 1-25.

Horbach J (2008) Determinants of environmental innovation - New evidence from German panel data sources. Research Policy 37: 163-173.

Howells $\mathbf{J}$ (2006) Intermediation and the role of intermediaries in innovation. Research Policy 35: $715-728$.

Human SE and Provan KG (2000) Legitimacy building in the evolution of small-firm multilateral networks: A comparative study of success and demise. Administrative Science Quarterly 45: 1-3.3.

Ingstrup MB (2010) The role of clusters facilitator. International Journal of Globalization \& Small Business 4: 25-40.

Kirkels Y and Duysters G (2010) Brokerage in SME networks. Research Policy 39: 375-385.

Knowles K and Espinosa A (2009) Towards an holistic framework for environmental change: The role of normative behaviour and informal networking to enhance sustainable business practices. Systemic Practice and Action Research 22: 275-291.

Lefebvre P (2013) Organising deliberate innovation in knowledge clusters: From accidental brokering to purposeful brokering processes. International Journal of Technology Management 63: 212-243.

Leydesdorff L and Etzkowitz H (1996) Emergence of a triple-helix of university-industry-government relations. Science and Public Policy 23: 279-286.

Lowndess V and Skelcher C (1998) The dynamics of multi-organizational partnerships: An analysis of changing modes of governance. Public Administration 76: 313-333.

Malecki EJ (2012) Regional social capital: Why it matters. Regional Studies 46: 1023-1039.

Martin R (2009) Roepke lecture in economic geography - Rethinking regional path dependence: Beyond lock-in to evolution. Economic Geography 86: 1-27.

McCauley SM and Stephens JC (2012) Green energy clusters and socio-technical transitions: Analysis of a sustainable energy cluster for regional economic development in Central Massachusetts, USA. Sustain Science 7: 213-225.

McDermott GA, Corredoira RA and Kruse G (2009) Public-private institutions as catalysts of upgrading in emerging market societies. Academy of Management Journal 52: 1270-1296.

McLaughlin P (2012) Ecological modernization in evolutionary perspective. Organization Environment 25: $178-196$.

Miller K, McAdam M and McAdam R (2014) The changing university business model: A stakeholder perspective. $R \& D$ Management 44: 265-287.

Moss T (2009) Intermediaries and the governance of sociotechnical networks in transition. Environment and Planning A 41: 1480-1495.

Patterson M, Humphreys D and Pettiford L (2003) Conceptualizing global environmental governance: From interstate regimes to counter-hegemonic struggles. Global Environmental Politics 3: 1-10.

Pihkala T, Harmaakorpi V and Pekkarinen S (2007) The role of dynamic capabilities and social capital in breaking socio-institutional inertia in regional development. International Journal of Urban and Regional Research 31: 836-853.

Posch A (2010) Industrial recycling networks as starting points for broader sustainability-oriented cooperation? Journal of Industrial Ecology 14: 242-257.

Priestley JL and Samaddar S (2007) Multi-organizational networks: Three antecedents of knowledge transfer. International Journal of Knowledge Management 3: 86-99.

Provan KG, Fish A and Sydow J (2007) Interorganizational networks at the network level: A review of the empirical literature on whole networks. Journal of Management 33: 479-516.

Rafiqui P (2009) Evolving economic landscapes: Why new institutional economics matters for economic geography. Journal of Economic Geography 9: 329-353. 
Ranga M and Etzkowitz H (2013) Triple helix systems: An analytical framework for innovation policy and practice in the knowledge society. Industry and Higher Education 27: 237-262.

Rodríguez-Pose A (2013) Do institutions matter for regional development? Regional Studies 47: $1034-1047$.

Sapsed J, Grantham A and De Fillippi R (2007) A bridge over troubled waters: Bridging organisations and entrepreneurial opportunities in emerging sectors. Research Policy 36: 1314-1334.

Schrank A and Whitford J (2011) The anatomy of network failure. Sociological Theory 29: 151-177.

Snow CC, Miles RE and Coleman HJ Jr (1992) Managing 21st century network organizations. Organizational Dynamics 20: 5-20.

Spiro E, Acton RM and Butts CT (2013) Extended structures of mediation: Re-examining brokerage in dynamic networks. Social Networks 35: 130-143.

Stovel K and Shaw L (2012) Brokerage. Annual Review of Sociology 38: 139-158.

Störmer E (2008) Greening as strategic development in industry change - Why companies participate in eco-networks. Geoforum 39: 32-47.

Vinnova (2013) Företag inom miljösektorn (Vinnova Analys 2013: 06).

Walker G, Kogut B and Shan W (1997) Social capital, structural holes and the formation of an industry network. Organization Science 8: 109-125.

Wetzstein S and Le Heron R (2010) Regional economic policy 'in-the-making': Imaginaries, political projects and institutions for Auckland's economic transformation. Environment and Planning A 42: $1902-1924$.

Whitford J (2012) Waltzing, relational work, and the construction (or not) of collaboration in manufacturing industries. Politics \& Society 40: 249-272.

Brita Hermelin is Professor in Human Geography at Centre for Municipality Studies, Linköping University. Her research interests are in local and regional development and strategic planning and governance.

Hans Rämö is Associate Professor in the Stockholm Business School at Stockholm University, Sweden. His research interests are in temporal and spatial factors of management and markets in relation to communication, Corporate Social Responsibility (CSR), networks, and philosophy and sociology of science. 